\title{
Nitrogen (N) for Citrus Trees ${ }^{1}$
}

\section{Mongi Zekri and Tom Obreza²}

This publication is part of a series about understanding nutrient requirements for citrus trees. For the rest of the series, visit http://edis.ifas.ufl.edu/ topic_series_citrus_tree_nutrients.

To maintain a viable citrus industry, Florida growers must consistently and economically produce large, highquality fruit crops from year to year. Efficiently producing maximum yields of high-quality fruit is difficult without understanding soil and nutrient requirements of bearing citrus trees. Most Florida citrus is grown on soils inherently low in fertility with low cation exchange capacity (CEC) and low water-holding capacity, thus soils are unable to retain sufficient quantities of available plant nutrients against leaching caused by rainfall or excessive irrigation.

Seventeen elements are considered necessary for the growth of green plants: carbon $(\mathrm{C})$, hydrogen $(\mathrm{H})$, oxygen $(\mathrm{O})$, nitrogen $(\mathrm{N})$, phosphorus $(\mathrm{P})$, potassium $(\mathrm{K})$, magnesium $(\mathrm{Mg})$, calcium $(\mathrm{Ca})$, sulfur $(\mathrm{S})$, manganese $(\mathrm{Mn})$, zinc $(\mathrm{Zn})$, iron $(\mathrm{Fe})$, copper $(\mathrm{Cu})$, boron $(\mathrm{B})$, chlorine $(\mathrm{Cl})$, molybdenum (Mo), and nickel (Ni). Plants obtain $\mathrm{C}, \mathrm{H}$, and $\mathrm{O}$ from carbon dioxide and water. The remaining elements, called the "mineral nutrients," are obtained from the soil. Mineral nutrients are classified as macronutrients and micronutrients. The term "macronutrients" refers to those elements that plants require in large amounts $(\mathrm{N}, \mathrm{P}, \mathrm{K}$, $\mathrm{Mg}, \mathrm{Ca}$, and S). The term "micronutrients" applies to plant nutrients that are essential to plants but are needed only in small amounts ( $\mathrm{Mn}, \mathrm{Zn}, \mathrm{Fe}, \mathrm{Cu}, \mathrm{B}, \mathrm{Cl}, \mathrm{Mo}$, and Ni). This publication reviews the nitrogen $(\mathrm{N})$ requirements of citrus trees.

\section{Introduction}

Meeting the world's escalating food needs cannot be achieved without fertilizer input. Without fertilizer, the world would produce only about half as much food, and more forested and marginal lands would have to be put into production. Inorganic commercial fertilizer plays a critical role in the world's food security, and it is important from both yield and food quality perspectives. Intensifying production and increasing yield on limited arable land are clearly important to secure a sufficient food supply, and fertilizer plays a critical role in these goals. Intensifying production is increasingly essential to meet the challenge of future food demands. However, this intensification must be done while also minimizing environmental impacts. The 4R Nutrient Stewardship Framework (i.e., right fertilizer source, right rate, right time, and right place) is therefore very important.

\section{Nitrogen Functions}

Nitrogen $(\mathrm{N})$ is of special importance because plants need this nutrient in large amounts. Nitrogen is also easily lost from soil and fairly expensive to supply. A major factor in successful farming is the grower's ability to manage $\mathrm{N}$ efficiently. Nitrogen has numerous functions in plants, and essentially all life processes depend on this nutrient. Nitrogen occurs chiefly in amino acids, proteins, and enzymes. The most active nitrogenous compounds occur largely in the protoplasm and nuclei of plant cells. Among them are the enzymes that speed up biochemical processes.

1. This document is SL378, one of a series of the Department of Soil and Water Science, UF/IFAS Extension. A version of this article was previously published in Citrus Industry magazine. Original publication date: July 2013. Visit the EDIS website at http://edis.ifas.ufl.edu.

2. Mongi Zekri, multicounty citrus UF/IFAS Extension agent; and Tom Obreza, professor and interim associate dean for Extension; UF/IFAS Extension, Gainesville, FL 32611. 
Table 1. Guidelines for interpretation of orange tree leaf N (\%) analysis based on 4- to 6-month-old spring flush leaves from nonfruiting twigs.

\begin{tabular}{|l|c|c|c|c|c|}
\hline & Deficient & Low & Optimum & High & Excessive \\
\hline $\mathrm{N}$ & $<2.2$ & $2.2-2.4$ & $2.5-2.7$ & $2.8-3.0$ & $>3.0$ \\
\hline
\end{tabular}

An abundant supply of essential $\mathrm{N}$ compounds is required in each plant cell for normal cell division, growth, and respiration. Even the green leaf pigment chlorophyll, which enables plants to use the energy of sunlight to form sugars from carbon dioxide and water, is a nitrogenous compound. A high concentration of $\mathrm{N}$ is found in young, tender plant tissues, including shoot tips, buds, and new leaves. This $\mathrm{N}$ is present mostly as protein, and it constantly moves and undergoes chemical changes. As new cells form, much of the protein moves from older cells to newer ones, especially when the total $\mathrm{N}$ content of the plant is low. While $\mathrm{N}$ moving to new tissue conserves $\mathrm{N}$ in the plant, the overall yield and quality can be at risk because of the reduced $\mathrm{N}$ supply to the plant.

Proper functioning of $\mathrm{N}$ in plant nutrition requires a sufficient supply of other essential elements, particularly phosphorus $(\mathrm{P})$, potassium $(\mathrm{K})$, calcium $(\mathrm{Ca})$, and magnesium $(\mathrm{Mg})$. If one or more of these elements is in short supply, the addition of $\mathrm{N}$ may not produce optimum growth. Plants experiencing poor nutrition often are susceptible to disease, mature late, and produce poor-quality fruit. However, if the nutrient balance and total supply are sufficient, significant growth of dark green foliage occurs. Nitrogen is the mineral element most used by citrus trees to produce leaves, flowers, and fruit, although $\mathrm{Ca}$ and $\mathrm{K}$ are also used in great amounts.

Nitrogen is the key component in mineral fertilizers applied to citrus groves. $\mathrm{N}$ has more influence on tree growth, appearance, and fruit production/quality than any other mineral element. Nitrogen affects the absorption and distribution of practically all other elements, and it is particularly important to the tree during flowering and fruit set.

\section{Nitrogen Deficiency}

Trees grown where plant-available $\mathrm{N}$ is limited may appear normal but undersized. These stunted trees carry little fruit load and can be highly erratic in bearing habit. Affected trees bloom sparsely, flush irregularly, and produce limited twig and leaf growth. Severe $\mathrm{N}$ starvation causes a general yellowing of the foliage. This symptom can be observed particularly on well-nourished trees that have a sharp reduction in their $\mathrm{N}$ supply.
Nitrogen deficiency first appears on older leaves and then proceeds toward younger leaves. Deficiency symptoms are characterized by light yellowish-green leaves. The veins are only slightly lighter in color than tissue in between. New leaves are small, thin, fragile, and light green in color. Leaves on new flushes are greener than leaves on the old flushes. Mature green leaves slowly bleach to a mottled irregular green and yellow pattern, become entirely yellow, and then abscise. $\mathrm{N}$-deficient trees are stunted with a thin canopy, and the crop is reduced as a result. The fruit peel tends to be smooth and pale in color, and the juice has lower soluble solids and acid concentrations. If $\mathrm{N}$ is deficient during the summer and fall when the fruit is expanding and maturing, some of the green leaves turn yellow and may abscise. Trees constantly short of $\mathrm{N}$ are stunted with irregular and very short twig growth. Twig dieback can occur, and crop production is greatly reduced.

Table 2. Effects of $\mathrm{N}$ on citrus fruit quality.

\begin{tabular}{|c|c|}
\hline Variable & Rating \\
\hline \multicolumn{2}{|c|}{ Juice Quality } \\
\hline Juice Content & + \\
\hline Soluble Solids (SS) & + \\
\hline Acid $(A)$ & + \\
\hline SS/A Ratio & - \\
\hline Juice Color & + \\
\hline Solids/Box & + \\
\hline Solids/Acre & + \\
\hline \multicolumn{2}{|c|}{ External Fruit Quality } \\
\hline Size & - \\
\hline Weight & - \\
\hline Green Fruit & + \\
\hline Peel Thickness & + \\
\hline \multicolumn{2}{|c|}{ Increase (+), Decrease (-) } \\
\hline
\end{tabular}

The ability to distinguish between $\mathrm{N}$ deficiency and the deficiency of other elements is very important. Symptoms of $\mathrm{Mg}$ deficiency at later stages can be confused with $\mathrm{N}$ deficiency. Growers must always remember that yellow leaves are not necessarily an indication of $\mathrm{N}$ deficiency. Nitrogen deficiency can be distinguished by the general nature of the yellowing of foliage throughout the entire tree with the absence of any distinctive leaf pattern. Nitrogen deficiency in Florida is most commonly observed after 
flowering but before the summer rainy season begins. In many cases, the foliage of such trees becomes greener during the summer rainy season, particularly if a small crop has set. Magnesium deficiency develops in the summer and causes complete yellowing of the leaves in the fall or early winter with no possible re-greening unless $\mathrm{Mg}$ fertilizer is applied.

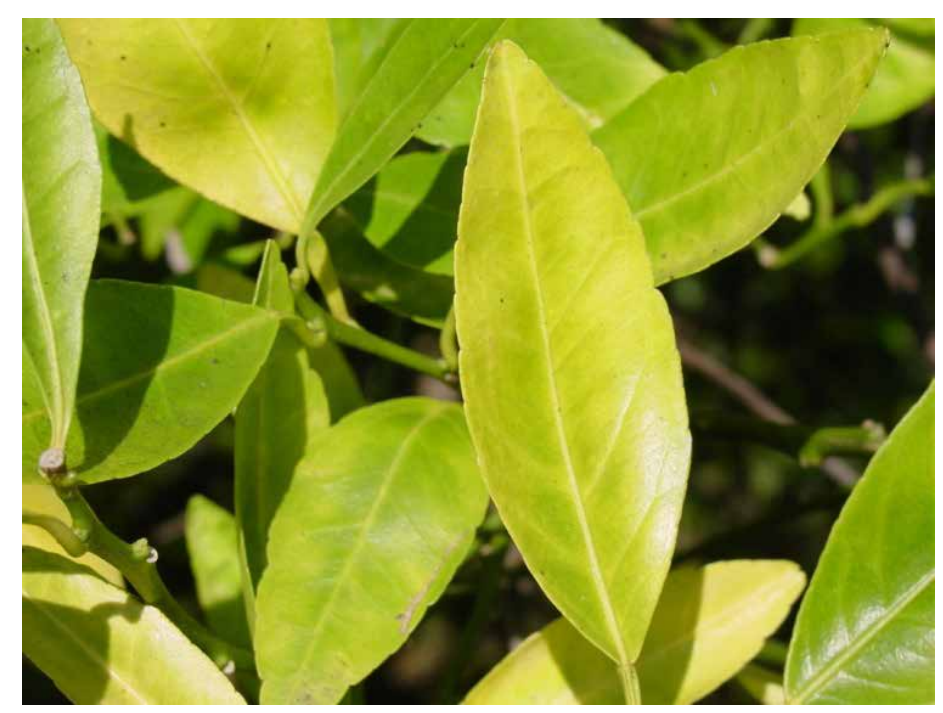

Figure 1. Nitrogen-deficient leaves.

Credits: M. Zekri

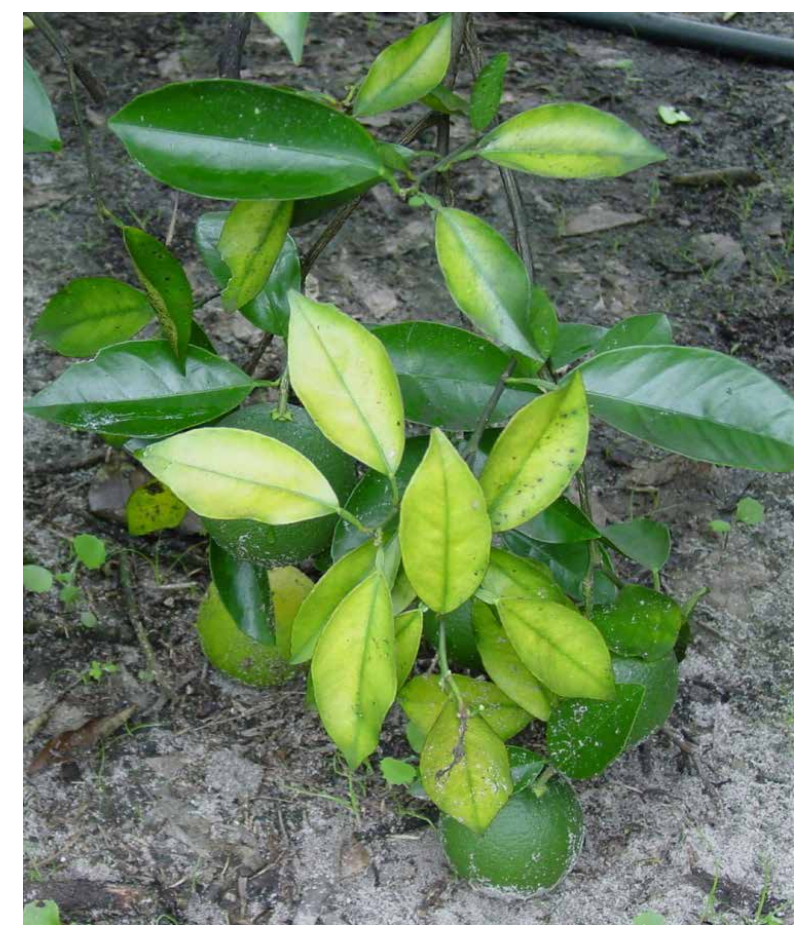

Figure 2. Magnesium-deficient leaves.

Credits: M. Zekri
The main cause of $\mathrm{N}$ deficiency is a lack of available $\mathrm{N}$ in the soil, which can be caused by a number of factors. Nitrogen leaching can occur because of heavy summer rainfall or over-irrigation on a highly porous soil or a combination of these factors. Water-logging of the soil can cause $\mathrm{N}$ loss through denitrification, which in turn may lead to a temporary $\mathrm{N}$ deficiency that is relieved by dry weather. $\mathrm{N}$-deficient weak or old trees can be improved by frequently applying small doses of $\mathrm{N}$ fertilizer. Foliar sprays of $\mathrm{N}$ fertilizer sources such as low-biuret urea, calcium nitrate, or potassium nitrate are a very efficient and rapid way to correct $\mathrm{N}$ deficiency.

\section{Conclusion}

Supplying sufficient nutrition should be a high-priority management practice for every grower. An appropriate nutrient balance using fertilizer management is necessary to achieve sufficient plant nutrition for best fruit yield and quality. If an element is below the critical level, yield production falls even though the other elements are kept in good supply. Balanced use of plant nutrients corrects nutrient deficiencies and toxicities, improves soil fertility, increases nutrient- and water-use efficiency, enhances crop yields and fruit quality, develops tree tolerance to pests, diseases, and other stresses, and improves environmental quality. 